\title{
Analysis of Factors Affecting the Human Development Index in West Kalimantan Province using Data Panel Data Regression
}

\author{
Uray Hety Humaira, Jaka Nugraha*) \\ Statistics Department, FMIPA, Islamic University of Indonesia \\ *Corresponding author: jnugraha@ uii.ac.id
}

\begin{abstract}
Abstrak
Pembangunan di seluruh wilayah Indonesia terus dilakukan, termasuk di Provinsi Kalimantan Barat. Namun demikian sampai dengan tahun 2015, pencapaian pembangunan manusia di tingkat Nasional masih yang cukup rendah dan pencapaian di Kabupaten/Kota cukup bervariasi. Indeks Pembangunan Manusia (IPM) merupakan salah satu ukuran pencapaian pembangunan manusia yang dipengaruhi oleh banyak faktor. Dalam makalah ini dilakukan analisis untuk mengetahui faktor-faktor yang mempengaruhi IPM di Kabupaten dan Kota Provinsi Kalimantan Barat dengan menggunakan Analisis Regresi data panel berdasarkan data dari tahun 2012 sampai tahun 2015. Diperoleh hasil analisis bahwa model regresi terbaik adalah Fixed Effect Model dengan dengan nilai $\mathrm{R}^{2}$ sebesar $99.853 \%$. Variabel yang mempengaruhi IPM adalah variabel Angka Harapan Hidup (AHH), Pendapatan per Kapita Disesuaikan (Pengeluaran), Rata-rata Lama Sekolah (RLS), Harapan Lama Sekolah (HLS), dan Produk Domestik Regional Bruto Atas Harga Konstan (PDRB).
\end{abstract}

Kata kunci : Regresi Data Panel, Model Efek Tetap, Indeks Pembangunan Manusia.

\begin{abstract}
Development in the country is growing including in the West Borneo Province. However in 2015, the achievement of human development at the National level is quite low, while the District and City varied considerably. Human Development Index is one of the parameter for human development that are affected by many factors. In this paper, analysis for identify the factors for human development index in West Kalimantan Province by using Regression Analysis was conducted. Regression was based on time series data from 2012 until 2015. It is found that Fixed Effect Model is the best regression model with the $R^{2}$ of $0.99853 \%$. The influencing variables are Life Expectancy (AHH), Adjusted Per Capita (Expenditure), School Average (RLS), School Expectation (HLS), and Gross Regional Domestic Product at Constant Price (GRDP).
\end{abstract}

Keywords : Panel Data Regression, Fixed Effect Model, Random Effect Model, Human Development Index.

\section{Introduction}

$H D I$ is a measure of development of a region. The calculation of $H D I$ consists of 3 dimensions, namely health dimension, education dimension, and expenditure dimension (decent standard of living) (UNDP, 2015).

$H D I$ is used to classify whether a country is a developed country, a developing country or an 
underdeveloped country, and also to measure the influence of economic policy on quality of life.

By 2015, HDI in West Kalimantan Province reaches $65.59 \%$ means development level is included in the medium category. With a life expectancy of 69.8 years, the expected length of school is 12.25 years, the average length of school is 6.93 years and per capita expenditure per year is 8279.34 (Thousand Rupiah) (Badan Pusat Statistik, 2015).

Both the HDI average in districts / cities, as well as the average $H D I$ in the province of West Kalimantan, both experienced a slowing growth. It is seen that the movement of value per year is slower than the national average of $H D I$ (Indonesia). The movement from the $H D I$ average of District / City and the HDI average of West Kalimantan province in each year is $0.68 \%$ and $0.81 \%$. Unlike the average national $H D I$ value (Indonesia), the annual difference reaches $4 \%$ more than the average of District/Municipal HDI and HDI of West Kalimantan Province.

Meirianti (2016) conducted an analysis using the fixed effect model of HDI data in 38 Regencies / Cities in East Java Province in 2010-2014. The results show that the level of poverty, health spending and economic spending have a positive and significant impact, education spending has a positive but not significant effect on the HDI.

This is what causes researchers interested to analyze the factors that affect the deeper HDI. By using panel data, we combine time series data and cross-sectional data to provide more data, as well as obtain more complete and diverse information.

\section{Panel Data Regression}

A Hdata set $H$ containing observations on a single phenomenon observed over multiple time periods is called a " $H$ time series $H$ ". A data set containing observations on multiple phenomena observed at a single point in time is called " $H$ cross-sectional $H$ " (where each individual, sampling unit, data point is observed only once). A data set containing observations on multiple phenomena observed over multiple time periods is called "panel data" (which implies that each individual, sampling unit, data point is observed in more than one time period). Panel data analysis do not require that the time period in which different individuals or sampling units are observed are exactly the same. 
The panel data is a combination of cross section and time series data, that is, some of the same individuals are observed in a certain period of time. A panel data regression differs from a regular time-series or cross-section regression in that it has a double subscript on its variables, i.e.

$$
y_{i t}=X_{i t}{ }^{\prime} \beta+e_{i t}
$$

$t=1,2,3, \ldots, T ; i=1,2,3, \ldots, N$

with $i$ denoting households, individuals, firms, countries, etc. and $t$ denoting time. The $i$ subscript, therefore, denotes the cross-section dimension whereas $t$ denotes the time-series dimension. $\beta$ is $(K+1) \times 1$ and $X_{i t}$ is the $i t$ th observation on $K$ explanatory variables.

There are three types of panel data regression : Common Effect Model, Fixed Effect Model and Random Effect Model.

\section{a. Common Effect Model (CEM)}

The common effect model is estimation which combines time series and cross section data. Parameters $\beta$ can be estimated using the OLS (Ordinary Least Square) method (Baltagi, 2005). The model in equation (1) is called CEM. $e_{i t}$ is an error component which is assumed to have mean 0 and homogeneous variance in time. $\beta$ are the effect of changes in $\mathrm{X}$ that are assumed to be constant in time and cross-section.

\section{b. Fixed Effect Model}

According to Gujarati (2004) the term "fixed effect" is because even though the intercept is different for each subject, each interception of each value does not change over time. According to Rosadi (2011), the FEM model is:

$$
Y_{i t}=X_{i t}{ }^{\prime} \beta+c_{i}+d_{t}+e_{i t}
$$

with $c_{i}$ denotes the unobservable individual-specific effect, $d_{t}$ denotes the constants that depend on time $t$. In this case, the $c_{i}$ are assumed to be fixed parameters to be estimated and the remainder disturbances stochastic with $\mathrm{e}_{\mathrm{it}}$ independent and identically distributed IID $\left(0, \sigma^{2}\right)$.

If the model contains the $\mathrm{c}_{\mathrm{i}}$ and $\mathrm{d}_{\mathrm{t}}$ components, the model is called a twoway FEM, whereas if $c_{i}=0$ and $d_{t}=0$ the model is called one-way FEM. For one-way FEM, it is often assumed that the component $d_{t},=0$, so it has a model:

$$
\begin{array}{r}
Y_{i t}=X_{i t}{ }^{\prime} b+d_{t}+e_{i t} \\
\text { c. } \quad \text { Random Effect Model. }
\end{array}
$$

When using FEM, we cannot see the influence of various characteristics that are constant in time, or constant between individuals. For this purpose REM can be used, which is generally written as follows: 


$$
\begin{aligned}
& Y_{i t}=X_{i t}{ }^{\prime} b+e_{i t} ; \\
& e_{i t}=u_{i}+v_{t}+w_{i t}
\end{aligned}
$$

The assumptions used for the error component are

$$
\begin{array}{ll}
u_{i} \sim N\left(0, \sigma_{u}^{2}\right) ; & v_{t} \sim N\left(0, \sigma_{v}^{2}\right) \\
w_{i t} \sim N\left(0, \sigma_{w}^{2}\right) &
\end{array}
$$

\section{Materials and Methods}

The data that will be analyzed are Human Development Index (HDI), Gross Regional Domestic Product at Constant Price (GRDP), Adjusted Per Capita (Expenditure), School Expectation (HLS), School Average $(R L S)$, and Life Expectancy (AHH) of West Kalimantan Province in 20122015. Data is taken from the Badan Pusat Statistik (BPS) report, which is "Kalimantan Barat dalam Angka" in 2012-2015.

The author determine the panel data regression analysis is an appropriate choice to determine whether Expenditure, HLS, RLS, AHH and GRDP affect the HDI.

\section{Result and Discussion}

The Average of Expenditure, HLS, RLS, AHH, GRDP and HDI in 14 districts and cities of West Kalimantan Province in 2012 to 2015 are shown in Figure 1.
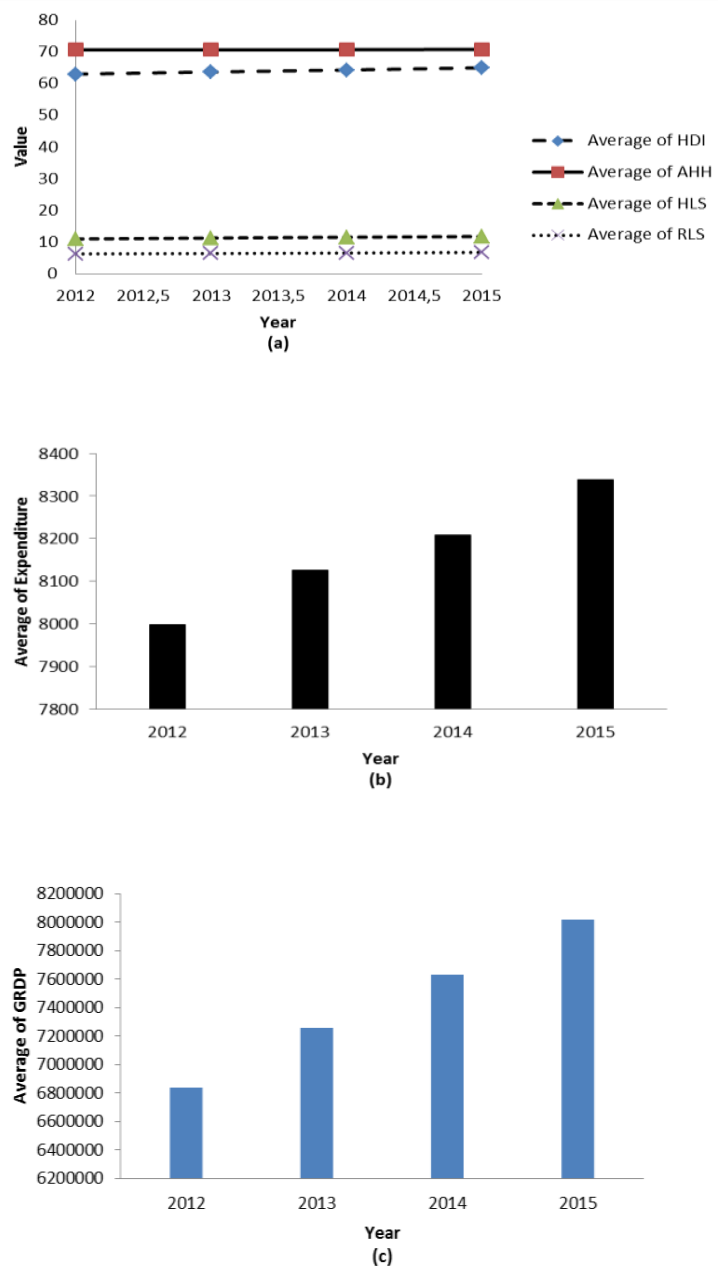

Figure 1 Average of each variable

In Figure 1, it is shown that all observed variables increase every year and the magnitude of the increase varies.

Then proceed with using R Studio application to do regression analysis of panel data, then got output as follows

\section{(1) Modeling \\ a. Common Effect Model (CEM)}

Table 1. F test for CEM

\begin{tabular}{cccc}
\hline F-Count & F-Table & P-Value & Decision \\
\hline 4625.44 & 2.40 & $<2.22$ & Significant \\
& & $\times 10^{-16}$ & \\
\hline
\end{tabular}


From Table 1 , the value of $F_{\text {count }}=$ $4625.44>F_{\text {table }}=2.40$ and $p$-value $\leq$ $2.22 \times 10^{-16}$ which is less than 0.05 it is decided to reject the initial hypothesis $\left(\mathrm{H}_{0}\right)$, which means together independent variables affect the dependent variable.

Table 2. $\mathrm{T}$ test for CEM

\begin{tabular}{lllll}
\hline \multicolumn{1}{c}{ Variable } & Coefficient & P-Value & $\begin{array}{c}\text { Significant } \\
\text { Level }\end{array}$ & Decision \\
\hline Constant & 1.6745 & $3.25 \times 10^{-1}$ & 0.05 & $\begin{array}{l}\text { Not } \\
\text { AHH }\end{array}$ \\
Expenditure & $1.8628 \times 10^{-1}$ & $2.20 \times 10^{-16}$ & 0.05 & Significant \\
HLS & 1.0871 & $2.20 \times 10^{-16}$ & 0.05 & Significant \\
RLS & $8.5981 \times 10^{-1}$ & $2.20 \times 10^{-16}$ & 0.05 & Significant \\
GRDP & $2.3627 \times 10^{-8}$ & $7.59 \times 10^{-3}$ & 0.05 & Significant \\
\hline
\end{tabular}

In pooled regression of $A H H$, Expenditure, $H L S, R L S$ and GRDP have significant effect on HDI variable because the $p$-value value is smaller than the significance level value of $5 \%$, so the initial hypothesis $H_{0}$ is rejected.

Then obtained value of $R^{2}$ (coefficient of determinant) equal to 0.99784. This can be interpreted that in pooled regression analysis of $A H H$, Expenditure, HLS, RLS and PDRB influence variable of $H D I$ equal to $99.784 \%$. While the rest of $0.216 \%$ influenced by other variables that are not analyzed in the regression model.

\section{b. Fixed Effect Model (FEM)}

Table 3. F test for FEM

\begin{tabular}{cccc}
\hline $\begin{array}{c}\text { F- } \\
\text { Count }\end{array}$ & $\begin{array}{c}\text { F- } \\
\text { Table }\end{array}$ & P-Value & Decision \\
\hline 5016.46 & 2.47 & $2.22 \times 10^{-16}$ & Significant \\
\hline
\end{tabular}

From Table 3, the value of $F_{\text {count }}=$ $5016.46>\mathrm{F}_{\text {table }}=2.47$ and $p$-value < $2.22 \times 10^{-16}$ which is less than 0.05 it is decided to reject the initial hypothesis $\left(\mathrm{H}_{0}\right)$. This means that together independent variables affect the dependent variable.

Table 4. T Test for FEM

\begin{tabular}{lllll}
\hline \multicolumn{1}{c}{ Variable } & Coefficient & P-Value & $\begin{array}{c}\text { Significant } \\
\text { Level }\end{array}$ & Decision \\
\hline AHH & $3.7276 \times 10^{-1}$ & $2.07 \times 10^{-4}$ & 0.05 & Significant \\
Expenditure & $1.4865 \times 10^{-3}$ & $2.20 \times 10^{-16}$ & 0.05 & Significant \\
HLS & 1.1480 & $2.20 \times 10^{-16}$ & 0.05 & Significant \\
RLS & 1.4236 & $2.30 \times 10^{-16}$ & 0.05 & Significant \\
GRDP & $-9.6664 \times 10^{-8}$ & $4.08 \times 10^{-7}$ & 0.05 & Significant \\
\hline
\end{tabular}

In the fixed effect model of the $A H H$, expenditure, HLS, RLS and GRDP have significant effect on the $H D I$ variable because the $\mathrm{p}$-value is less than the significance level of $5 \%$, so the initial hypothesis $\mathrm{H}_{0}$ is rejected.

The value of $\mathrm{R}^{2}$ is 0.99853 . This can be interpreted that in the analysis of fixed effect model estimation, only the $A H H$, expenditure, HLS, RLS and GRDP variables affecting the HDI variable is $99.853 \%$. While the rest of $0.147 \%$ influenced by other variables that are not analyzed in the regression model.

\section{c. Random Effect Model}

Table 5. F test for REM

\begin{tabular}{cccc}
\hline $\begin{array}{c}\text { F- } \\
\text { Count }\end{array}$ & $\begin{array}{c}\text { F- } \\
\text { Table }\end{array}$ & P-Value & Decision \\
\hline 2005.45 & 2.40 & $2.22 \times 10^{-16}$ & Significant \\
\hline From the value $\mathrm{F}_{\text {count }}=2005.45>$
\end{tabular}

$F_{\text {table }}=2.40$. When viewed from the 
value of $p$-value $=2.22 \times 10^{-16}$ which is less than 0.05 it was decided to reject the initial hypothesis $\left(\mathrm{H}_{0}\right)$. This means that together independent variables affect the dependent variable.

Table 6. T test for REM

\begin{tabular}{lllll}
\hline Variable & Coefficient & P-Value & $\begin{array}{c}\text { Significant } \\
\text { Level }\end{array}$ & Decision \\
\hline Constant & 6,5667 & 0,06901 & 0.05 & Significant \\
AHH & $3,6528 \times 10^{-1}$ & $4,861 \times 10^{-9}$ & 0.05 & Significant \\
Expenditure & $1,1745 \times 10^{-3}$ & $2,20 \times 10^{-16}$ & 0.05 & Significant \\
HLS & 1,1797 & $2,20 \times 10^{-16}$ & 0.05 & Significant \\
RLS & 1,3643 & $2,30 \times 10^{-16}$ & 0,05 & Significant \\
GRDP & $-4,1899 \times 10^{-8}$ & 0,02473 & 0,05 & Significant \\
\hline
\end{tabular}

In the model of random effect of $A H H$, expenditure, HLS, RLS and GRDP have significant effect on the $H D I$ variable because the $\mathrm{p}$-value value is smaller than the significance level value of $5 \%$, so the initial hypothesis $\mathrm{H}_{0}$ is rejected (Table 6).

Then obtained value of determinant coefficient $\left(\mathrm{R}^{2}\right)$ equal to 0.99504. This can be interpreted that in the analysis of random effect model of $A H H$, expenditure, HLS, and GRDP influence the HDI variable of $99.504 \%$. While the rest of $0.496 \%$ influenced by other variables that are not analyzed in the regression model.

\section{(2) Model Identification}

\section{a. Chow Test}

Table 7. The result of Chow Test

\begin{tabular}{ccccc}
\hline $\begin{array}{c}\text { Influence } \\
\text { Test }\end{array}$ & F-count & F-table & p-value & Decision \\
\hline F test & 118.11 & 2.00 & $<2.2 \times 10^{-16}$ & Significant \\
\hline
\end{tabular}

From the value of $\mathrm{F}_{\text {count }}=118.11$ $>\mathrm{F}_{\text {table }}=2.00$, and from $\mathrm{p}$-value $\left(<2.2 \times 10^{-16}\right)$ less than 0.05 it is decided to reject the initial hypothesis $\left(\mathrm{H}_{0}\right)$. This means that the appropriate model is a fixed effect model.

\section{b. Hausmann Test}

Table 8. The result of Hausmann Test

\begin{tabular}{ccccc}
\hline $\begin{array}{c}\text { Influence } \\
\text { Test }\end{array}$ & $\chi_{\text {count }}^{2}$ & $\chi_{\text {table }}^{2}$ & p-value & Decision \\
\hline Chi- & 21.434 & 11.07 & 0.0006705 & Significant \\
Square & & & & \\
test & & & & \\
\hline
\end{tabular}

From Table 8 , the value of $\chi_{\text {count }}^{2}=$ $21.434>\chi_{\text {table }}^{2}=11.07$, and from $\mathrm{p}$ value $=0.0006705$ less than 0.05 it was decided to reject the initial hypothesis $\left(\mathrm{H}_{0}\right)$. This means that the appropriate model is a fixed effect model.

\section{c. Lagrange Multiplier Test}

Table 9. The result of Lagrange Multiplier Test

\begin{tabular}{ccc}
\hline Influence Test & p-value & Decision \\
\hline Lagrange & $1,024 \times 10^{-6}$ & Significant \\
Multiplier test & & \\
\hline
\end{tabular}

From Table 9, the value of $p$ value $=1.024 \times 10^{-6}$ is less than 0.05 it was decided to reject the initial hypothesis $\left(\mathrm{H}_{0}\right)$. This means that the appropriate model is the Random Effect. 


\section{(3) Model Spesifications}

Table 10. Breusch Pagan test for model spesifications FEM

\begin{tabular}{|c|c|c|c|c|c|}
\hline \multicolumn{2}{|c|}{ Hypothesis } & $\chi_{\text {count }}^{2}$ & $\chi_{\text {table }}^{2}$ & P-value & Decision \\
\hline $\begin{array}{l}\mathrm{H}_{0} \\
\mathrm{c}_{\mathrm{i}}=0, \\
\mathrm{~d}_{\mathrm{t}}=0\end{array}$ & : & 37.955 & 5.99 & $5.731 \times 10^{-9}$ & $\begin{array}{l}\mathrm{H}_{0} \text { rejected, there' } \\
\text { two ways effect. }\end{array}$ \\
\hline $\begin{array}{l}\mathrm{H}_{0} \\
\mathrm{c}_{\mathrm{i}}=0\end{array}$ & : & 22.549 & 3.84 & $2.048 \times 10^{-6}$ & $\begin{array}{l}\mathrm{H}_{0} \text { rejected, the } \\
\text { individual effect. }\end{array}$ \\
\hline $\begin{array}{l}\mathrm{H}_{0} \\
\mathrm{~d}_{\mathrm{t}}=0\end{array}$ & : & 15.405 & 3.84 & $8.674 \times 10^{-5}$ & $\begin{array}{l}\mathrm{H}_{0} \text { rejected, the } \\
\text { time effect. }\end{array}$ \\
\hline
\end{tabular}

From Table 10, the value of $\chi_{\text {count }}^{2}$ and $P$-value can be seen that the fixed effect model used has a two-way specification, which is influenced by individual effects and time effects. From the results of Chow, Hausmann and Breuch-Pagan test above, it can be concluded that the appropriate model to explain the variables forming $A H H$, Expenditure, HLS, RLS and GRDP directly affect $H D I$ is a fixed effect model. With the model results are formed namely:

$$
\begin{aligned}
& H D I=3.7276 \times 10^{-1} A H H+ \\
& 1.4865 \times 10^{-3} \text { Expenditure }+1.1480 \\
& H L S+1.4236 \text { RLS-9.6664 } \times 10^{-8} \\
& G R D P+c_{i}+d_{t}
\end{aligned}
$$

and the value of individual and time effects explained in Table 11.

From Table 11, the table shows that the district and city of West Kalimantan Province has the largest individual value is Landak District that is equal to 2.4815989. This indicates that the Human Development Index in
Sub-district Landak is higher than the Regency and City in West Kalimantan Province. While the smallest Individual value found in Pontianak with the value of HDI of -5.5247228. Which means, that the value of HDI in the city has the lowest value among districts and cities in West Kalimantan Province.

Table 11. The value of Individual Effects

\begin{tabular}{rlr}
\hline Individual & Districts/Cities & $\begin{array}{l}\text { Effect } \\
\text { value }\end{array}$ \\
\hline 1 & Bengkayang & 0.1185357 \\
2 & Kapuas Hulu & 0.1132201 \\
3 & Kubu Raya & 0.8627460 \\
4 & Kayong Utara & -0.1249034 \\
5 & Ketapang & 0.8302479 \\
6 & Landak & 0.0796319 \\
7 & Melawi & 0.0352745 \\
8 & Mempawah & 0.0991690 \\
9 & Pontianak & -2.1012999 \\
10 & Sambas & 0.1494578 \\
11 & Sanggau & 0.7393289 \\
12 & Sekadau & 0.0366270 \\
13 & Singkawang & -1.1981008 \\
14 & Sintang & 0.3600650 \\
\hline
\end{tabular}

Table 12. The value of Time Effects

\begin{tabular}{ccc}
\hline Period & Year & Effect value \\
\hline 1 & 2012 & 10.38715 \\
2 & 2013 & 10.44532 \\
3 & 2014 & 10.49128 \\
4 & 2015 & 10.56705 \\
\hline
\end{tabular}

The influence of time is the value that shows the difference in mean of inter-year HDI in West Kalimantan Province. This value indicates that each period will have a different constant value depending on the dt value of each year. Which means in the $1^{\text {st }}$ period that is in 2012 has a value of time effect of 10.38715 , the second period that is in 
2013 has a value of time effect of 10.44532 , and so on.

\section{(4) Assumption Test}

\section{a. Multicolinearity Test}

Table 13. The result of Multicolinearity Test

\begin{tabular}{cc}
\hline Independent Variable & VIF value \\
\hline AHH & 1.043987 \\
Expenditure & 2.514837 \\
HLS & 1.925316 \\
PDRB & 1.844396 \\
\hline
\end{tabular}

From Table 13, it is known that the overall independent variable has a VIF value $<10$, so there is no multicollinearity problem.

\section{b. Heteroscedasticity Test}

Table 14. The result of Heteroscedasticity Test

\begin{tabular}{cccc}
\hline $\begin{array}{c}\text { Influence } \\
\text { Test }\end{array}$ & P-Value & $\begin{array}{c}\text { Significant } \\
\text { Level }\end{array}$ & Decision \\
\hline $\begin{array}{c}\text { Breusch } \\
\text { Pagan }\end{array}$ & 0.1473 & 0.05 & $\begin{array}{l}\text { Failed to } \\
\text { reject } \mathrm{H}_{0}\end{array}$ \\
\hline
\end{tabular}

From Table 14, therefore the value of $\mathrm{p}$-value is greater than 0.05 which means accepting the initial hypothesis. This means that there is no problem of heteroscedasticity.

\section{Conclusions}

The correct model for data panel is fixed effect model, with two-way effect. Thus, together the $A H H$, expenditure, HLS, RLS and GRDP variables, affect $H D I$ in 14 districts and cities in West Kalimantan at $99.853 \%$. the rest of $0.147 \%$ GRDP is influenced by other factors outside these variables.

$$
\text { Variables AHH, Expenditure, }
$$

$H L S$, and RLS 14 districts and cities in West Kalimantan Province have a positive and significant relationship with HDI 14 districts / cities in West Kalimantan Province. Each increase of 1 (one) rupiah from the value of the variable with the value of constant variable then the value of $H D I$ will each increase $\quad 3.7276 \times 10^{-3}, \quad 1.4865 \times 10^{-3}$, 1.1480 , and 1.4236 .

\section{References}

Baltagi, B. H.,, 2005, Econometrics Analysis of Panel Data ( $\left.3^{\text {rd }} \mathrm{ed}\right)$, England, John Wiley \& Sons Ltd

Badan Pusat Statistik, 2012, Kalimantan Barat Dalam Angka, Pontianak, BPS

Badan Pusat Statistik, 2013, Kalimantan Barat Dalam Angka, Pontianak, BPS

Badan Pusat Statistik, 2014, Kalimantan Barat Dalam Angka, Pontianak, BPS

Badan Pusat Statistik, 2015, Kalimantan Barat Dalam Angka, Pontianak, BPS.

Gujarati, 2004, Basic Econometric, $\left(4^{\text {th }}\right.$ Ed.), New York, The McGrawHill Companies

Meirianti. 2016. Pengaruh Kemiskinan, Belanja Pemerintah Bidang Pendidikan, Kesehatan dan 
Ekonomi Terhadap Tingkat IPM di 38 Kabupaten/Kota Provinsi Jawa Timur, 2010-2014. Tugas Akhir. Yogyakarta : Universitas Gajah Mada.

Rosadi, Dedi., 2011, Analisis Ekonometrika dan Runtun Waktu Terapan dengan R, Yogyakarta, Andi Offset

UNDP, 2015, Human Development Report: Human Development Index 2015, New York 